\title{
BUDIDAYA IKAN LELE DUMBO (Clarias gariepinus) DAN IKAN NILA HITAM (Oreochromis niloticus) DALAM EMBER (BUDIKDAMBER)
}

\author{
(Aquaculture of Catfish (Clarias gariepinus) and Black Nile Tilapia (Oreochromis niloticus) \\ in the Buckets)
}

\author{
Deby Setyani, Yusanti Mantuh, dan Tania Serezova Augusta \\ Fakultas Perikanan Universitas Kristen Palangka Raya \\ Jalan RTA. Milono Km. 8,5 Palangka Raya \\ Penulis koresponden : debysetyani@gmail.com,
}

Article Submitted: 26-02-2021

Article Accepted: 21-05-2021

\begin{abstract}
The capacity of the environment is one of the factors which needs to be given attention in aquaculture. With the help of technology and even little media be an increase in the capacity of the environment to catfishes (Clarias gariepinus), black Nile tilapia's (Oreochromis niloticus), and vegetables in a bucket. The system of the aquaculture of fish in the bucket uses a simple concept and needn't massive capital because needn't room or ponds. The purpose of this activity is to find the growth of catfishes, black Nile tilapia's as well as vegetables in the limited area with techniques aquaculture in a bucket, so that can be applied with tiny scales in the household. This activity was carried out in two months from November 2020 up to December 2020 in Palangka Raya. The method is; $a$. The preparatory stage of vegetable media $b$. The preparatory stage of media the aquaculture of fish c. Data analysis. Based on the evaluation and monitoring growth catfishes revealed the presence of absolute $15,21 \mathrm{~cm}$ long growth and heavy growth is 87,94 gr. The success rate of life as long as maintenance shows the range $66,66 \%$. While for black Nile tilapia's long growth absolute $6,07 \mathrm{~cm}$ and heavy growth is $13,66 \mathrm{gr}$. The success rate of living in tilapia for maintenance shows a value of $46,66 \%$. Kale planted in aquaculture containers for 2 months can be harvested as much as 2 times. The results of water quality temperature, $\mathrm{pH}$, and dissolved oxygen (DO) both at the beginning and at the end of the study showed a range of catfishes and tilapias that could still tolerate growth.
\end{abstract}

Keywords: Aquaculture of fish in the bucket, growth, catfish, black Nile tilapia.

\section{PENDAHULUAN}

Sehubungan kondisi dunia yang dihebohkan oleh terjadinya wabah pandemi COVID-19 dimana Indonesia juga terkena dampaknya, mengakibatkan segala aktivitas orang banyak menjadi terhambat. Pemerintah akhirnya membatasi aktivitas masyarakat di luar rumah dengan menganjurkan bekerja dan belajar dari rumah. Kebutuhan pokok orang banyakpun menjadi sulit terpenuhi. Oleh karena itu dibutuhkan usaha dalam mencukupi kebutuhan hidup sehari-hari. Salah satu sumber kebutuhan protein hewani yang masih dapat dipenuhi oleh masyarakat luas adalah dengan cara memelihara ikan baik itu di kolam, sungai, danau atau media lainnya. Namun dengan seiring kegiatan pembangunan, tempat budidaya ikan semakin berkurang, sehingga daya dukung dalam pembudidayaan ikan perlu diperhatikan. Adanya perkembangan teknologi, media yang kecil sekalipun dapat membantu meningkatkan daya dukung lingkungan (Nursandi, 2018). Salah satu teknologi dimaksud yaitu membudidayakan 
ikan lele, nila dan sayuran dalam ember. Sistem kerja dari budikdamber (Budidaya Ikan Dalam Ember) yaitu model akuaponik mini yang menggabungkan budidaya ikan dan sayuran secara bersama di lahan terbatas. Prinsip sistem budidaya akuaponik adalah menggunakan lahan yang hemat dan efisiensi dalam pemanfaatan hara yang berasal dari sisa pakan dan metabolisme ikan (Setijaningsih dan Umar, 2015).

Konsep budikdamber memiliki nilai tambah karena sederhana, tidak membutuhkan modal besar serta ukuran kolam yang luas. Diharapkan sstem budikdamber dapat menjadi salah satu cara mengatasi lahan budidaya ikan dan membantu memenuhi salah satu sumber protein hewani masyarakat di masa pandemi.

Penelitian ini bertujuan untuk mengetahui bagaimana teknik budikdamber serta megetahui pertumbuhan ikan lele dumbo (Clarias gariepinus) dan ikan nila hitam (Oreochromis niloticus) dalam ember sekaligus sayuran pada lahan yang terbatas. Manfaat dari kegiatan ini adalah sebagai bahan informasi agar dapat diterapkan dalam skala kecil rumah tangga dan semua pihak khususnya dalam bidang perikanan.

\section{METODE PENELITIAN}

\section{Waktu dan Tempat}

Kegiatan dilaksanakan selama 2 (dua) bulan dari tanggal 01 November 2020 sampai dengan 31 Desember 2020 di Palangka Raya.

\section{Alat dan Bahan}

Alat yang digunakan adalah netpot sebagai wadah media tanam sayuran, media tanam rockwoll, kain planel untuk menjaga rockwoll tetap basah dan ember ukuran 80 liter sebagai wadah budidaya. Bahan yang digunakan adalah bibit kangkung, ikan lele sebanyak 60 ekor, ikan nila sebanyak 60 ekor, Pelet Prima Feed PF800 dan Prima
Feed LP 1, timbangan digital, penggaris, kertas lakmus dan termometer.

\section{Pelaksanaan}

Tahapan Persiapan Media Sayuran :

1. Semai terlebih dahulu biji kangkung didalam media tanam rockwoll selama 1-2 hari.

2. Sediakan netpot sebagai wadah tumbuh sayuran (kangkung).

3. Masukkan kain panel di netpot agar rockwoll sebagai media tanam sayuran tetap dalam kondisi basah.

Tahap Persiapan Media Budidaya Ikan :

1. Sediakan 2 buah ember yang berkapasitas 80 liter, kemudian masing-masing diisi air sebanyak 60 liter dan diamkan 2 hari.

2. Setelah 2 hari masukkan ikan lele dumbo yang berukuran antara 4-6 cm pada ember 1 dan ikan nila hitam yang berukuran antara 3-5 cm pada ember 2, dengan jumlah ikan 60 ekor untuk masing-masing ember.

3. Pemberian pakan ikan dengan frekuensi sebanyak 2 x sehari secara at satiation (sampai kenyang). Pada awal pemeliharaan diberi pakan jenis Prima Feed PF800 sedangkan pada bulan kedua sesuai bukaan mulutnya ikan diberi pakan jenis Prima Feed LP 1 .

4. Melakukan penyipon air ketika kualitas air menurun.

\section{Analisis Data}

1. Pertumbuhan Panjang Mutlak

Pengukuran panjang mutlak dilakukan untuk melihat tingkat pertumbuhan panjang benih ikan lele dumbo dan ikan nila hitam. Diukur dengan persamaan sebagai berikut (Effendie, 1997):

$$
\mathbf{L}=\mathbf{L t}-\mathbf{L o}
$$

Keterangan:

$\mathrm{L}=$ Pertumbuhan panjang $(\mathrm{cm})$

Lt $=$ Pertumbuhan panjang sesudah pemeliharaan $(\mathrm{cm})$

Lo $=$ Pertumbuhan panjang sebelum pemeliharaan $(\mathrm{cm})$ 
2. Pertumbuhan Berat Mutlak

Pengukuran berat mutlak dilakukan untuk mengetahui biomassa ikan lele dumbo dan ikan nila hitam pada tiap ember. Diukur dengan persamaan sebagai berikut (Effendie, 1997):

$$
\mathbf{W}=\mathbf{W t}-\mathbf{W o}
$$

Keterangan :

$\mathrm{W}=$ Pertumbuhan berat mutlak $(\mathrm{g})$

$\mathrm{Wt}=$ Berat rata-rata akhir $(\mathrm{g})$

Wo $=$ Berat rata-rata awal $(\mathrm{g})$

3. Tingkat Kelangsungan Hidup (SR)

Kelangsungan hidup (SR) merupakan perhitungan perbandingan jumlah ikan lele dumbo dan ikan nila hitam yang hidup dari awal pemeliharaan sampai akhir pemeliharaan. Dihitung menggunakan rumus sebagai berikut (Goddard, 1996):

$$
\mathrm{SR}=\frac{\mathrm{Nt}}{\mathrm{NO}} \times 100 \%
$$

Keterangan :

SR : kelangsungan hidup (\%)

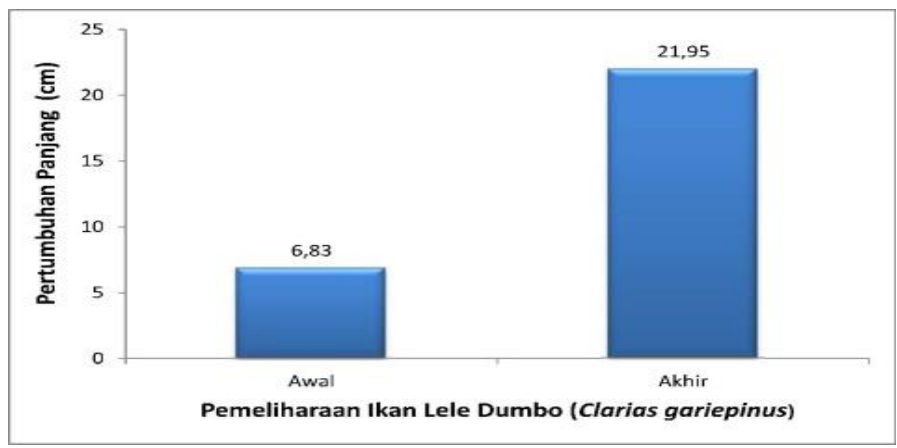

Gambar 2. Diagram Pertumbuhan panjang rata-rata $(\mathrm{cm})$ Ikan Lele Dumbo yang dibudidaya di Ember selama 2 bulan.

Menurut Susetya dan Harahap (2018) kisaran pertumbuhan panjang ikan lele yang dipelihara di ember selama 2 (dua) bulan mencapai ukuran > $17 \mathrm{~cm}$. Pertumbuhan lele yang dipelihara di ember
$\mathrm{Nt}$ : jumlah ikan pada akhir penelitian (ekor)

No : jumlah ikan pada awal penelitian (ekor)

\section{Kualitas Air}

Parameter kualitas air yang diukur meliputi suhu, $\mathrm{pH}$ meter, dan DO. Suhu diukur menggunakan termometer, $\mathrm{pH}$ diukur menggunakan kertas lakmus, dan DO diukur menggunakan DO meter. Kualitas air diukur pada awal dan akhir penelitian

\section{HASIL DAN PEMBAHASAN}

\section{Pertumbuhan Ikan Lele Dumbo (Clarias gariepinus)}

Pertumbuhan panjang mutlak ikan lele dumbo yang dipelihara. Panjang mutlak pada awal tebar rata-rata berkisar $6,83 \mathrm{~cm}$. Sedangkan pada akhir magang berkisar antara $21,95 \mathrm{~cm}$ sehingga pertumbuhan panjang mutlak sekitar $15,12 \mathrm{~cm}$ selama 2 bulan pemeliharaan. 


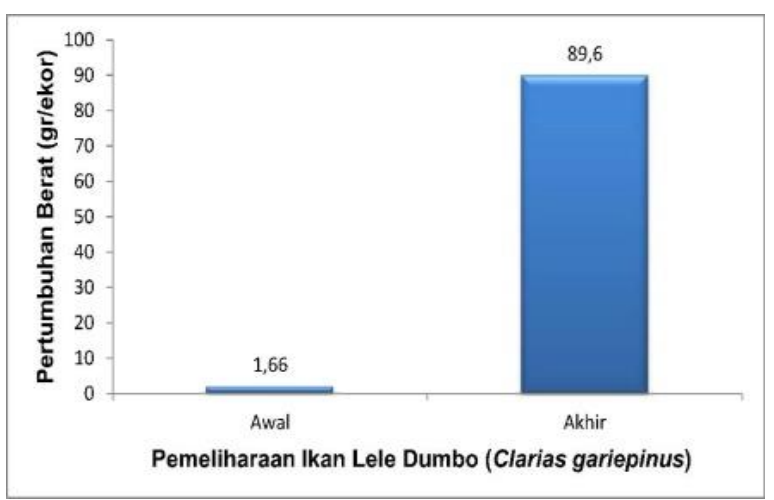

Gambar 3. Diagram Pertumbuhan berat rata-rata $(\mathrm{cm})$ Ikan Lele Dumbo yang dibudidaya di Ember selama 2 bulan.

Pertumbuhan berat mutlak pada ikan lele yang dipelihara, berat rata-rata awal tebar ikan lele dumbo berkisar 1,66 gr/ekor sedangkan berat rata-rata akhir pemeliharaan berkisar 89,6 gr/ekor, sehingga pertumbuhan berat mutlak berkisar 87,94 gr/ekor selama 2 bulan pemeliharaan. Menurut Nursandi (2018) bahwa rata-rata pertumbuhan ikan lele yang dibudidaya dengan sistem budikdamber selama pemeliharaan 42 hari dengan rata-rata berat awal tebar 1,75 g/ekor dan 14,33 g/ekor memiliki berat rata-rata diakhir pemeliharaan sebesar 18,45 g/ekor dan 47,74 g/ekor.

\section{Pertumbuhan Ikan Nila Hitam (Oreochromis niloticus)}

Pertumbuhan panjang mutlak pada ikan nila hitam yang dipelihara. Panjang mutlak pada awal tebar rata-rata kisaran 2,35 $\mathrm{cm}$. Adapun pada akhir magang rata-rata berkisar $8,42 \mathrm{~cm}$. Sehingga pertumbuhan panjang mutlak sekitar $6,07 \quad \mathrm{~cm}$ selama 2 bulan pemeliharaan.

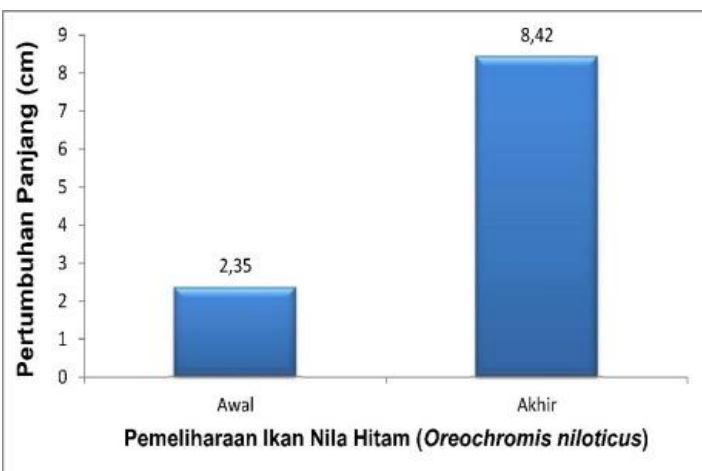

Gambar 4. Diagram Pertumbuhan panjang rata-rata $(\mathrm{cm})$ Ikan Nila Hitam yang dibudidaya di Ember selama 2 bulan

Pertumbuhan yang tidak signifikan ini disebabkan ikan nila kurang bisa beradaptasi di wadah pemeliharaan. Biasanya ikan nila dipelihara di wadah yang luas dan memiliki kadar oksigen yang cukup. Ruang yang sempit dan tidak adanya asupan oksigen baik dari luar maupun dari aliran air serta tingginya ammonia menyebabkan energi yang seharusnya untuk pertumbuhan hanya digunakan untuk bertahan hidup. 


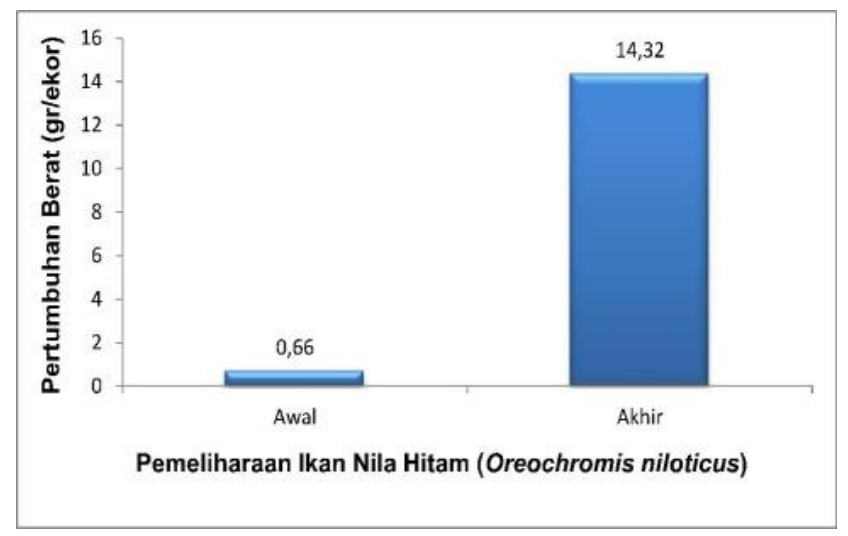

Gambar 5. Diagram Pertumbuhan berat rata-rata $(\mathrm{cm})$ Ikan Nila Hitam yang dibudidaya di Ember selama 2 bulan.

Pertumbuhan berat mutlak pada pemeliharaan ikan nila hitam selama 2 bulan di ember menunjukkan berat sekitar 13,66 gr/ekor. Pada pemeliharaan awal ukuran tebar rata-rata $2 \mathrm{~cm}$ dan berat sekitar 0,3 gr menunjukkan pertumbuhan tertinggi dengan ukuran rata-rata $5,3 \mathrm{~cm}$ dan berat rata-rata sekitar 2,41 gr.

\section{Tingkat Kelangsungan Hidup Ikan Lele Dumbo dan Ikan Nila Hitam}

Hasil tingkat kelangsungan hidup pada ikan lele dumbo dan ikan nila hitam dapat dilihat pada Tabel 2 .

Tabel 2. Data Tingkat kelangsungan hidup (\%) ikan lele dumbo dan ikan nila hitam

\begin{tabular}{lc}
\hline \multicolumn{1}{c}{ Ikan } & Tingkat Kelangsungan Hidup (\%) \\
\hline Lele Dumbo & 66,66 \\
Nila Hitam & 46,66 \\
\hline
\end{tabular}

Tingkat kelangsungan hidup ikan lele selama 2 bulan penelitian menunjukkan nilai sebesar 66,66 \%. Tingkat kelangsungan hidup tersebut masih rendah yaitu dibawah $70 \%$. Hal ini kemungkinan disebabkan kualitas benih, ukuran benih, padat tebar yang tinggi dan kualitas air yang menurun. Pemeliharaan ikan lele di ember yang dilakukan Nursandi (2018) juga menunjukkan tingkat kelangsungan hidup yang rendah dibawah $70 \%$ yaitu untuk ukuran tebar 5-7 cm memiliki kisaran 53,33 dan untuk ukuran tebar 12-14 cm memiliki kisaran $60,42 \%$. Dari hasil penelitian ini terlihat bahwa semakin besar ukuran tebar, maka persentase tingkat kehidupan ikan lele dumbo yang dipelihara dalam media budikdamber akan semakin tinggi.

Tingkat kelangsungan hidup pada ikan nila selama 2 bulan penelitian menunjukkan nilai sebesar 46,66 \%. Rendahnya tingkat kelangsungan hidup pada ikan nila selain ukuran benih dan padat tebar yang tinggi juga karena asupan oksigen yang kurang. Pada awal bulan pemeliharaan ikan nila lebih banyak terlihat berada di permukaan air dan kurang memiliki respon untuk makan yang menyebabkan pergantian air harus dilakukan 3-5 hari sekali. Pada bulan kedua hampir terjadi kematian massal sehingga memutuskan untuk menggunakan aerasi untuk menambah asupan oksigen. Menurut Handayani et al (2020) bahwa ikan 
yang cocok dibudidaya adalah ikan yang dapat bertahan hidup dengan kadar oksigen rendah seperti ikan gabus, patin, lele, gurame, dan betok.

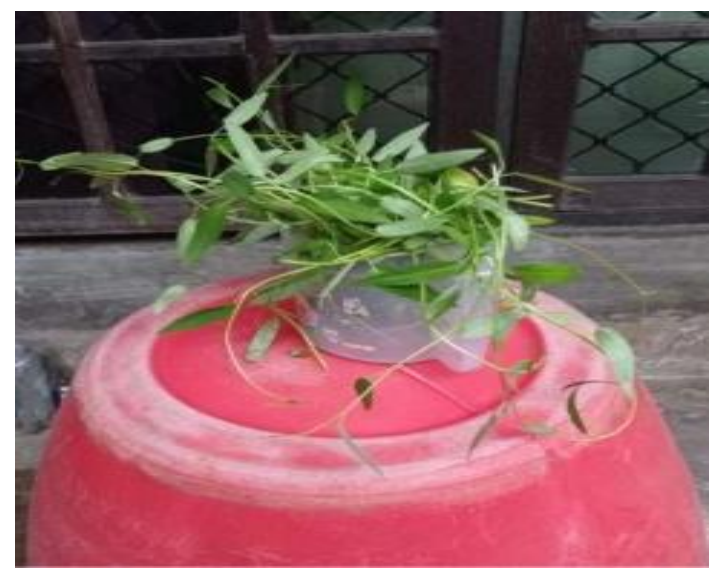

Gambar 6. Kondisi ikan nila hitam mati akibat kekurangan oksigen

\section{Pertumbuhan Tanaman Kangkung}

Tanaman kangkung yang ditanam di wadah budidaya di semai dari biji. Panen tanaman kangkung pertama kali dilakukan pada umur 30 hari dan panen selanjutnya pada hari ke-25 setelah panen pertama, jadi selama pemeliharaan selama 2 bulan dapat dilakukan panen sebanyak 2 kali. Pertumbuhan kangkung sangat dipengaruhi asupan nutrient dan media tanam yang digunakan.

Dari hasil pertumbuhan kangkung dapat dikatakan bahwa tumbuhan kangkung dapat memanfaatkan hasil limbah ikan meskipun tidak maksimal seperti sistem akuaponik karena hanya memanfaatkan nutrient dari limbah ikan di permukaan air budidaya.

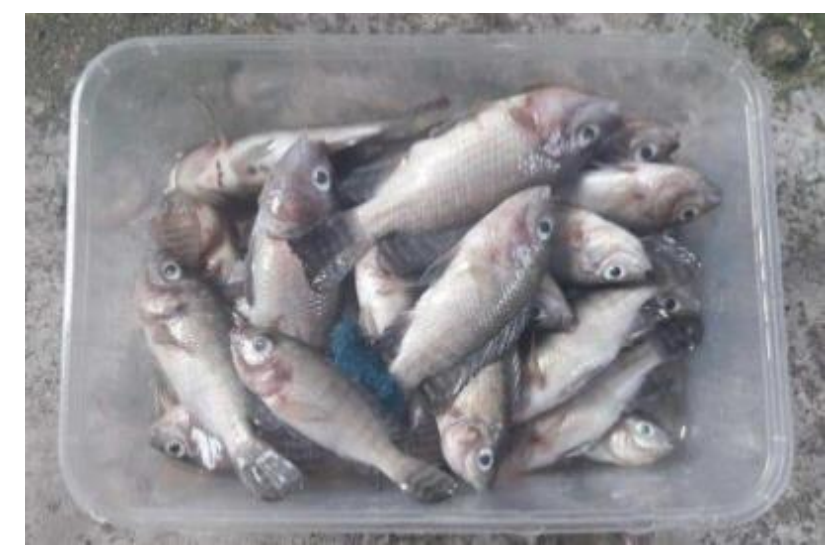

Gambar 7. Panen kangkung

\section{Kualitas Air}

Kualitas air baik pada awal maupun pada akhir masih dalam tahap toleransi ikan lele dumbo dan nila hitam untuk hidup dapat dilihat pada Tabel 3 . 
Tabel 3. Data Kualitas air selama penelitian ikan lele dumbo dan ikan nila hitam pada awal dan akhir

\begin{tabular}{|c|c|c|c|c|}
\hline \multirow{3}{*}{ Parameter } & \multicolumn{4}{|c|}{ Perlakuan } \\
\hline & \multicolumn{2}{|c|}{ Awal } & \multicolumn{2}{|c|}{ Akhir } \\
\hline & Lele & Nila & Lele & Nila \\
\hline Suhu $\left(^{\circ}\right)$ & 25 & 25 & 27 & 27 \\
\hline $\mathrm{pH}$ & 6 & 6 & 6 & 6 \\
\hline $\begin{array}{l}\mathrm{DO} \\
(\mathrm{mg} / \mathrm{L})\end{array}$ & 3,60 & 2,45 & 2,11 & 4,16 \\
\hline
\end{tabular}

Berdasarkan hasil pengamatan kualitas air yang diperoleh bahwa suhu pada saat awal dan akhir magang berkisar antara 25-27 ${ }^{\circ} \mathrm{C}$ pada kedua wadah budidaya. Rendahnya suhu diawal karena ember berada di dalam rumah sehingga tidak langsung terkena sinar matahari langsung. Sedangkan dilakukan pemindahan wadah budidaya dikarenakan tanaman kangkung tidak tumbuh dengan baik akibat kurangnya terkena sinar matahari sehingga fotosintesis pada tanaman tidak berlangsung dengan baik. Suhu pada masing-masing ember masih berada dalam batas yang layak bagi pertumbuhan ikan lele maupun nila. Suhu yang masih dapat ditoleransi oleh ikan lele yang dibudidaya dalam ember adalah sekitar $23{ }^{\circ} \mathrm{C}$ sampai $32{ }^{\circ} \mathrm{C}$. Sedangkan kualitas air media pemeliharaan ikan nila sesuai Badan Standarisasi Nasional (2009) harus memiliki rentang suhu $23{ }^{\circ} \mathrm{C}$ hingga $30{ }^{\circ} \mathrm{C}$.

Nilai $\mathrm{pH}$ baik pada awal dan akhir penelitian pada masing-masing perlakuan berkisar 6. Menurut Popma dan Masser (1999) kisaran $\mathrm{pH}$ air tersebut masih toleran untuk kelangsungan hidup dan pertumbuhan ikan lele dumbo dan nila hitam.

Nilai oksigen terlarut (DO) pada awal dan akhir penelitian berkisar antara $2,45-4,16 \mathrm{mg} / \mathrm{L}$. Nilai DO diakhir penelitian pada wadah budidaya ikan nila mendekati kisaran 4,16 mg/L dikarenakan sudah menggunakan aerator, sedangkan satu bulan pertama ikan nampak banyak berada di permukaan dan tidak memiliki selera makan. Menurut Mahyudin (2008) dan
Badan Standarisasi Nasional (2009) bahwa oksigen terlarut untuk budidaya lele dumbo dan ikan nila hitam $>3 \mathrm{mg} / \mathrm{L}$.

\section{KESIMPULAN DAN SARAN}

\section{Kesimpulan}

Hasil penelitian menunjukkan adanya pertumbuhan panjang mutlak pada ikan lele dumbo yang dipelihara yaitu 15,21 $\mathrm{cm}$ dan pertumbuhan berat mutlak adalah 87,94 gr/ekor. Tingkat kelangsungan hidup selama pemeliharaan menunjukkan kisaran 66,66\%. Sedangkan untuk ikan nila hitam pertumbuhan panjang mutlak yaitu $6,07 \mathrm{~cm}$ dan pertumbuhan berat mutlak adalah 13,66 gr/ekor. Tingkat kelangsungan hidup pada ikan selama pemeliharaan menunjukkan nilai sebesar 46,66 \%. Hasil pengukuran kualitas air yaitu suhu, $\mathrm{pH}$ dan oksigen terlarut (DO) baik pada awal dan akhir penelitian menunjukkan kisaran yang masih dapat ditoleransi oleh ikan nila untuk pertumbuhan.

Hasil pengukuran kualitas air yaitu suhu, $\mathrm{pH}$ dan oksigen terlarut (DO) baik pada awal dan akhir penelitian menunjukkan kisaran yang masih dapat ditoleransi oleh ikan nila untuk pertumbuhan.

\section{Saran}

Dapat dilakukan penelitian lanjutan tentang padat tebar pada ikan lele dikarenakan tingkat kelangsungan hidup ikan kurang dari $70 \%$. Untuk budidaya ikan nila hitam di sistem budikdamber tidak direkomendasikan dilakukan karena ikan banyak mati dan ketergantungan terhadap tambahan oksigen. 


\section{DAFTAR PUSTAKA}

Badan Standardisasi Nasional. 2009. SNI 7550:2009, Produksi Ikan Nila (Oreochromis niloticus Bleeker) Kelas Pembesaran di Kolam Air Tenang Author

Effendie. 1997. Biologi Perikanan. Yogyakarta : Yayasan Pustaka Nusatama.

Ghufron M dan Kordi HK. 2010. Buku Pintar Pemeliharaan Ikan Air Tawar

Ekonomis di Keramba Jaring Apung. Lily Publisher. Yogyakarta.

Goddard S. 1996. Feed Management in Intensive Aquaculture. Chapman and Hall. New York.

Handayani S, Taqwa ARZ, Fani DE, Nuroh L, Khoirunaili N, Utomo RA. 2020. Panduan Praktis Budikdamber sebagai Alternatif Peningkatan Perekonomian dan Ketahanan Pangan Masyarakat Desa Jabung Malang. Universitas Negeri Malang.

Irianni, R. 2006. Analisis Kelayakan Finansial Pembenihan dan Pendederan Ikan Nila Wanayasa Pada Kelompok Pembudidaya Mekarsari, Desa Tanjungsari, Kecamatan Pondoksalam, Kabupaten Purwakarta. Skripsi. Bogor: Institut Pertanian Bogor.

Mahyudin K. 2008. Panduan Lengkap Agribisnis Lele. Jakarta : Penebar Swadaya.

Nursandi J. 2018. Budidaya Ikan dalam Ember "Budikdamber" dengan
Aquaponik di Lahan Sempit. Prosiding Seminar Nasional Pengembangan Teknologi Pertanian. Lampung : Politeknik Negeri Lampung.

Popma, T, Masser, M. 1999. Tilapia Life History and Biology. Southern Regional Aquaculture Center Publication Np. 283

Saanin, H. 1984. Taksonomi dan Kunci identifikasi Ikan Jilid I. Binatjipta. Bandung.

Setijaningsih L, Umar C. 2015. Pengaruh Lama Retensi Air Terhadap Pertumbuhan Ikan Nila (Oreochromis niloticus) pada Budidaya Sistem Akuaponik dengan Tanaman Kangkung. Berita Biologi, Jurnal Ilmu-ilmu Hayati. ISSN 01261754636/AU3/P2MILIPI/07/2015 Vol 14 No.35:267275.

Supendi, M. R. Maulana dan S. Fajar. 2015. Teknik Budidaya Yumina-Bumina sistem Aliran Atas di Bak Terpal. Bul. Tek. Lit. Akuakultur Vol. 13 No. 1 Tahun 2015: 5-9.

Susetya E, Harahap ZA. 2018. Aplikasi Budikdamber (Budidaya Ikan Dalam Ember) untuk Keterbatasan Lahan Budidaya di Kota Medan. ABDIMAS TALENTA. 3(2): 416-420.

Suyanto SR. 2009. Budidaya Ikan Lele Edisi Revisi. Jakarta : Penebar Swadaya. 